\title{
Konstelacje krytyczne
}

\section{Dorota Kozicka, Katarzyna Trzeciak}

Tekst powstał w ramach grantu Konstelacje krytyczne. Strategie krytyki literackiej XX i XXI wieku [Nr 0184/NPRH/H2a/83/2016].

Pojęcie „konstelacji” w odniesieniu do badań literackich i studiów kulturowych ${ }^{1}$ w najszerszym zakresie określa relacje pomiędzy pojęciami a rzeczami, w ramach których jednostkowość rzeczy stawia opór uniwersalizującym tendencjom wyznaczanym przez pojęcie. Relacje te oparte są na zestawianiu i szeregowaniu, nie na hierarchicznym strukturyzowaniu.

Źródłem takiego ujęcia konstelacji jest rozpoznanie Waltera Benjamina ze Źródła dramatu żałobnego:

Idee mają się do rzeczy tak jak gwiazdozbiory mają się do gwiazd. Oznacza to przede wszystkim: nie są ani ich pojęciami, ani prawami. Nie służą poznaniu fenomenów, a te żadną miarą nie mogą stanowić kryterium istnienia idei. Znaczenie fenomenów dla idei wyczerpuje się raczej w ich elementach pojęciowych. Podczas gdy fenomeny poprzez swoje bytowanie, przez to, co jest im wspólne i co je różni, decydują o zakresie i treści pojęć, które je obejmują, ich stosunek do idei jest o tyle odwrotny, o ile idea jako obiektywna interpretacja fenomenów - czy raczej ich elementów - określa dopiero, w jakiej mierze elementy te przynależą do siebie nawzajem. Idee to wieczne konstelacje, elementy zostają ujęte jako punkty w tych konstelacjach, a dla fenomenów oznacza to, że są podzielone i jednocześnie scalone ${ }^{2}$.

Benjaminowska figura konstelacji dostarcza alternatywnej metody organizowania rzeczy w polu wiedzy, pozwala bowiem uniknąć Platońsko-Kantowskich problemów poznania, ufundowanych na rozdziale noumenów i fenomenów. Konstelacja wykracza poza ten dualizm, ukazując współzależność rzeczy i idei. Jak pisze David Carniglia, autor hasła Constellation:

\footnotetext{
${ }^{1}$ Takie szerokie ujęcie „konstelacji” jako strategii badawczej dla filozofii, studiów kulturowych oraz literaturoznawstwa proponuje David Carniglia, autor hasła: Constellation w The Encyclopedia of Literary and Cultural Theory - zob. The Encyclopedia of Literary and Cultural Theory, vol. 1: Literary Theory from 1900 to 1966, red. G. Castle, Willey-Blackwell 2011, s. 128-130.

${ }^{2}$ W. Benjamin, Źródło dramatu żałobnego w Niemczech, przeł. A. Kopacki, posłowie A. Lipszyc, Warszawa 2013, s. 17.
} 
„Rzeczy mogą być organizowane w taki sposób, że wyrastają z nich idee. Ale i same idee nie są radykalnie oddzielone od rzeczy"3. Innymi słowy, to nie rzeczy wyłaniają się z absolutnych idei, lecz właśnie idee mają źródło w materialności rzeczy.

W odróżnieniu od Platońskiego ujęcia idei Benjamin dostrzega ich materialne uwikłanie, dzięki czemu łączy estetyczną wrażliwość z materialistycznym widzeniem dzieła jako historycznego artefaktu. To właśnie dzięki takiemu połączeniu astronomiczna metafora konstelacji stała się podstawą rewizji konceptualizowania historii. W Pasażach, konstelacyjnej historii dziewiętnastowiecznego Paryża, Benjamin opisuje mediacyjną funkcję konstelacji jako tego, co nieciągłe, oparte na gwałtownym wtargnięciu, a przez to zakłócające przyczynowo-skutkową logikę historycznego poznania, będącą fundamentem oświeceniowego myślenia, faworyzującego przyczynowość i linearność. Konstelacyjne podejście do historii ma także konsekwencje dla postawy samego badacza. Odtąd jego zadaniem nie jest antykwaryczna rekonstrukcja, lecz kolekcjonowanie i zestawianie heterogenicznych elementów historycznych, pochodzących zarówno z teraźniejszości historycznego zjawiska, jak i współczesności jego badacza ${ }^{4}$.

Nie jest tak, iżby przeszłość rzucała światło na teraźniejszość albo teraźniejszość na przeszłość; lecz to obraz jest tym, w czym „byłość” piorunowym błyskiem tworzy konstelację z „teraz”. Inaczej mówiąc, obraz to dialektyka znieruchomiała. Albowiem o ile relacja teraźniejszości z przeszłością jest czysto czasowa, ciągła, o tyle związek między „byłością” i „teraz” ma charakter dialektyczny: nie jest upływem, lecz obrazem, czymś nieciągłym ${ }^{5}$.

W kontekście myślenia o historii Benjaminowska konstelacja zawdzięcza wiele Siegfriedowi Giedionowi, historykowi architektury, który zadanie każdego badacza historii określał jako „konstruowanie konstelacji z rozbitych fragmentów”. Zdaniem Giediona:

Znaczenie historii wyrasta z odkrywania związków. Dlatego właśnie pisanie o historii ma mniej do czynienia z faktami jako tymi, więcej natomiast z relacjami pomiędzy nimi. Te relacje zmieniają się wraz ze zmiennym punktem widzenia, gdyż, podobnie jak konstelacje gwiazd, są w nieustannej zmienności. Każdy prawdziwy obraz historyczny jest oparty na zależnościach, pojawiających się w wyborze historyka spośród pełni zdarzeń; wyborze zróżnicowanym w zależności od wieku czy dekady [...] $]^{6}$.

Akcentowana przez Giediona relacyjność konstelacji współgra z Benjaminowskimi ustaleniami, według których idee jawią się badaczowi i krytykowi jako znaczące we wzajemnych, zmiennych układach i powiązaniach. Dzięki tej przestrzennej metaforze autor Pasaży porzuca binarne opozycje i wskazuje na potrzebę symultanicznego rozumienia poprzez materialistyczne widzenie.

\footnotetext{
${ }^{3}$ D. Carniglia, Constellation, s. 129.

${ }^{4}$ Ta historyczna metoda daje, zdaniem Benjamina, możliwość „odkupienia” detali - fragmentów materialnych i „wybawienia” od totalizującej mocy pojęć. Mesjańska retoryka Benjamina, jak również jego nacisk na możliwość odróżnienia „idei” od „pojęć” stanie się przedmiotem krytyki Adorna, który zrewiduje pojęcie „konstelacji” - zob. N. Friesen, Wandering Star: The Image of the Constellation in Benjamin, Giedion and McLuhan, s. 2, <http://learningspaces.org/wordpress/wp-content/uploads/2013/06/Wandering-StarBenjaminGiedionMcLuhan21.pdf> [dostęp: 11.10.2017].

${ }^{5}$ W. Benjamin, Pasaże, red. R. Tiedemann, przeł. I. Kania, posłowie Z. Bauman, Kraków 2005, s. 508.

${ }^{6}$ S. Giedion, Mechanization Takes Command: A Contribution to Anonymus History, Oxford 1970, s. 2.
} 
Benjaminowskie pojęcie konstelacji stało się narzędziem „innowacyjnego rozumienia historii”, jednak późniejsze użycia tej metafory wskazują na jej skuteczność także w literaturoznawstwie czy studiach kulturowych. Wychodząc od Benjaminowskiej historyczności rzeczy i uzupełniając konstelacje o jej relacyjny status, Theodor Adorno dostarczył interesującego rozwinięcia potencjału astronomicznej metafory dla badań literackich. Autor Teorii estetycznej określił Benjaminowską konstelację jako „metafizyczną”, uwikłaną w mistycyzm i sam zwrócił się ku rozumieniu krytycznej funkcji sztuki jako odmowy jakiejkolwiek syntezy, summy i ahistorycznej uniwersalności' W rozważaniach Adorna konstelacja wymierzona jest przeciwko filozofii tożsamości na rzecz nieidentyczności, która nie redukowałaby tego, co pojedyncze do uniwersalnych kategorii rozumienia. W perspektywie badań literackich ta Adorniańska korekta pojęcia konstelacji okazała się inspiracją do stworzenie konstelacyjnego modelu lektury i potraktowania metafory konstelacji jako określenia samego procesu czytania: „jako artefakt historyczny, dzieło sztuki przypomina nam o upływie czasu; nie prezentuje siebie czytelnikowi w pierwotnym stanie oryginalnej koncepcji, lecz raczej jako akumulację lat, może i wieków zużycia, transmisji i odbioru, zniszczeń i rekonstrukcji”’.

W takim ujęciu konstelacyjny akt lektury staje się jedyną kondycją dzieła, bowiem praktyka czytania ujawnia się jako włączona w historyczną świadomość i zarazem staje się narzędziem, pozwalającym na odkrycie tego, co nie zostało o dziele powiedziane. W konstelacyjnym trybie lektury, proponowanym przez Renée R. Trilling, każdy wiersz z badanej przez nią średniowiecznej poezji anglosaskiej jest fragmentem przeszłości, która domaga się rozpoznania w swoim materialnym kształcie przy jednoczesnym uwzględnieniu estetycznej wartości. Oba te postulaty są możliwe do spełnienia właśnie dzięki rozpoznaniu konstelacyjności samego aktu lektury, historyczności, ale i jednostkowości dzieła. Jako konstelacja lektura tekstu pozwala odsłonić polityczność czasu, a także reaktywować to, co skutkiem różnie politycyzowanych czasowości musiało zostać wykluczone i zapomniane. Stawką konstelacyjnej praktyki lektury jest, jak pisze Trilling, odkrycie prawdy „nie w samym dziele, lecz w konstelacji. [...] Prawdy, która znajduje się w napięciu między podobieństwami i różnicami, między tym, co skrajne, i tym, co typowe"10. Efektem takiej lektury jest więc odkrycie złożonych praktyk dyskursywnych, które zdeterminowały i determinują nadal, w teraźniejszości czytającego, status interpretacyjny oryginalnego tekstu literackiego.

Przejście od Benjaminowskiego „mistycyzmu” konstelacji, poprzez Adorniańską materialność i heterogeniczną historyczność, aż do konstelacyjnego modelu lektury unaocznia ruch pojęcia konstelacji w naukach humanistycznych. To, mówiąc za Mieke Bal, „wędrujące pojęcie” ${ }^{11}$, które

\footnotetext{
${ }^{7}$ D. Carniglia, Constellation, s. 129.

${ }^{8}$ Wątpliwości Adorna wzbudziły szczególnie dwa aspekty Benjaminowskiego rozumienia konstelacji - przekonanie o odrębności idei i pojęć, prowadzące do maskowania przez pojęcia własnej pojęciowości oraz proklamowana „bezczasowość” konstelacji. Na ten drugi aspekt Adorno wskazywał, tłumacząc, że jeśli istotą konstelacji są relacje między gwiazdami, to ich „bezczasowość” jest nieuchronnie uwikłana w historyczną zmienność - zob. S. Jarvis, Constellations: Thinking the Non-identical, [w:] tegoż, Adorno: A Critical Introduction, New York 1998, s. 176.

${ }^{9}$ R.R. Trilling, Ruins in the Realm of Thoughts: Reading as Constellation in Anglo-Saxon Poetry, „The Journal of English and Germanic Philology" 2/2009, vol. 108, s. 143, <http://www.jstor.org/stable/20722719> [dostęp: 11.10.2017].

${ }^{10}$ Tamże, s. 148.

${ }^{11}$ Mówiąc o „wędrujących pojęciach”, Mieke Bal wskazuje na ich elastyczność, bowiem „wędrują one pomiędzy dyscyplinami i między poszczególnymi uczonymi, między okresami historycznymi i między rozproszonymi geograficznie społecznościami uczonych. Ich znaczenie, zasięg i wartość operacyjna są różne w różnych dyscyplinach”. Zob. M. Bal, Wędrujące pojęcia w naukach humanistycznych, przeł. M. Bucholc, Warszawa 2012, s. 40.
} 
od krytyki oświeceniowej wizji historii jako linearnego procesu poznania przeszło do metodologii badań literackich, określając proces lektury jako „nieustannej oscylacji pomiędzy indywidualną sferą ludzkiej historii i miejscem dzieła w historii rzeczy"12. Jedną z istotnych zasług zaadaptowania metafory konstelacji do badań literackich jest więc możliwość umieszczenia aktu interpretacji w polu tej oscylacji, które jest zarazem polem bitwy heterogenicznych sił, a konstelacyjny akt lektury zmierza do ich odsłonięcia i ujawniania ich oddziaływania na dzieło. Postrzeganie tekstu literackiego w konstelacji innych tekstów i interpretacja anachroniczna pozwalają rozpoznać nie tylko nieciągłości i antagonizmy jako efekty historycznych przemian lektur, ale także Benjaminowską „niezmienność” nie jako uniwersalną, bezczasową, a zatem i niekwestionowalną kategorię, lecz jako efekt działania dyskursów, opartych na totalizującej pracy pojęć.

Ta krótka geneza „wędrówek” metafory konstelacji nie wyczerpuje jej potencjału jako metody dla badań w naukach humanistycznych. Proponowane tu pojęcie „konstelacji krytycznej” odnosi się bowiem w dużej mierze do wszystkich wskazanych tu zastosowań, zmienia jednakże punkty swojej trajektorii, umieszczając w polu "materialnego artefaktu” dyskursy krytyki literackiej. Takie przesunięcie umożliwia nie tylko, jak proponowała Trilling, przekroczenie „milczenia dzieła”, lecz także stworzenie nowych form widzialności dyskursów krytycznych. W ramach tych form istotne jest ujawnienie warunków działania krytyki, nie w perspektywie historycznego rekonstruowania recepcji tekstów literackich, lecz demaskowania historycznie zmaterializowanego statusu języków krytycznych.

Pojęcie konstelacji pojawiło się już w polskich badaniach także w kontekście krytyki. W rozważaniach na temat krytyki literackiej jako przedmiotu badań historycznoliterackich Janusz Sławiński określił zespół tekstów „ukształtowany przez wspólne odniesienie do tego samego dzieła mianem „konstelacji”, uznał też konstelację za „jedno z najbardziej naturalnych zgrupowań wypowiedzi krytycznych" i za całość wyrazistszą od zbioru wypowiedzi jednego krytyka na różne tematy ze względu na to, że skupia ona „elementy rozmaitych faktów literackich”"13. Do tych rozważań odwoływał się Michał Głowiński, tworząc konstelację „Wyzwolenia”, podkreślał przy tym już na wstępie, że „[k]onstelacja mówi dużo także o tekstach krytycznych, które się na nią złożyły, a porównanie prac odnoszących się do jednego dzieła pozwala na pokazanie różnic i miejsc wspólnych, sprzyja ujawnieniu stylów krytycznych, krystalizujących się w rozważaniach o jednym przedmiocie, a także różnego rodzaju rozumień istoty krytyki, jej funkcji i zobowiązań"14. I zgodnie z tą deklaracją pokazywał osobliwości krytyki związanej z tym dziełem i przekonywał, że w konstelacji „Wyzwolenia” odzwierciedlają się najważniejsze właściwości krytyki literackiej epoki. W ujęciu Głowińskiego widać jednak, że najistotniejszym impulsem do tych „ujawnień” było samo dzieło Wyspiańskiego, jego oryginalność, pobudzająca/stymulująca - zdaniem badacza - do interpretacyjnej pomysłowości, do podejmowania szerokiej i zróżnicowanej problematyki i pokazywania krytycznego kunsztu. A znakomite, poprzez połączenie analitycznej precyzji, porównawczych ujęć i szerokiego kontekstu pojęciowego rozważania warszawskiego badacza zamykają się w granicach badań nad krytyką literacką danej epoki.

${ }^{12}$ T R.R. Trilling, Ruins in the Realm of Thoughts..., s. 147.

${ }^{13} \mathrm{~J}$. Sławiński, Krytyka literacka jako przedmiot badań historycznoliterackich, [w:] tegoż, Prace wybrane, t. IV, Kraków 2000, s. 149-150.

${ }^{14}$ M. Głowiński, Konstelacja „Wyzwolenia”, „Pamiętnik Literacki” 1990, nr 2, s. 35. 
W poświęconym badaniom nad krytyką literacką tekście Janusza Sławińskiego uwagi na temat konstelacji pojawiły się w ramach omawiania jednej z pięciu perspektyw badawczych, istotnych w badaniach nad historią krytyki - perspektywy obejmującej „świadectwa recepcji literatury w jakimś czasie i środowisku"15. I podporządkowane zostały (podobnie jak wszystkie konstatacje dotyczące różnorodności krytycznoliterackich wypowiedzi, sposobów ich funkcjonowania i możliwości analizowania) naczelnemu celowi teoretyczno-metodologicznego modelu badań nad krytyką, czyli odtworzeniu poszczególnych jednostek oraz całego procesu historycznoliterackiego:

Poszczególny przekaz podlegać może jednocześnie różnym interferującym zaszeregowaniom: jest elementem „konstelacji” współbudującej fakt literacki, składnikiem twórczości danego krytyka, należy do zbioru tekstów reprezentujących jakąś szkołę krytyczną, wchodzi do grupy wypowiedzi składających się na sformułowaną poetykę danego prądu, i tak dalej, i tak dalej. Za każdym razem inaczej lokuje się w porządku jednostek procesu historycznoliterackiego ${ }^{16}$.

Wypowiedzi krytyczne w obrębie konstelacji stanowią - zdaniem Sławińskiego - istotny komponent faktu literackiego, czyli całości tworzonej przez dzieło wraz z jego odbiorem w określonych warunkach socjalno-literackich. Warszawski teoretyk kładzie przy tym szczególny nacisk na to, że tylko taka, budowana na mocy różnorodnych i wielostronnych relacji całość (a nie sam utwór) jest jednostką procesu historycznoliterackiego. A projektowane na tych przekonaniach badania nad krytyką literacką mają „efektywnie uczestniczyć w zintegrowanej historii literatury"17. Wpisane więc zostają w naczelną zasadę odtwarzania istniejących kiedyś relacji, historycznej zobiektywizowanej rekonstrukcji.

W proponowanym tu modelowym ujęciu konstelacji krytycznych szczegółowe rozpoznania Sławińskiego, dotyczące wielostronnych relacji między dziełem literackim i odnoszącymi do niego tekstami, między samymi tekstami konstelacyjnymi oraz między tymi tekstami a „bezgłośną opinią publiczności" odgrywają znaczącą rolę. Jednak zasadnicze rozumienie zarówno samej konstelacji krytycznej, jak i celów jej badania jest radykalnie odmienne.

Różnice te wynikają, po pierwsze, z idącego tropem rozpoznań Waltera Benjamina, przekonania, że badacz/historyk nie tyle odtwarza/rekonstruuje "naturalnie istniejącą”, ile konstruuje konstelację. I dokonuje tego, zestawiając heterogeniczne elementy, pochodzące zarówno z teraźniejszości historycznego zjawiska, jak i współczesności jego badacza, a więc uwzględniając także samego siebie i własną perspektywę jako element konstelacji. W przypadku konstelacji krytycznych konstruowanych wokół konkretnego tekstu literackiego konsekwencją takiego myślenia jest również współobecność tekstów krytycznych powstających w różnym czasie (od pierwszych tekstów aż do „współczesności badacza”). Mamy więc do czynienia z konstelacją, która jest synchroniczna i diachroniczna zarazem, a ściślej rzecz ujmując - w układzie konstelacyjnym diachroniczność (historycznie uwarunkowane teksty) staje się synchroniczna. Przy uwzględnieniu „historycznej teraźniejszości” poszczególnych tekstów najistotniejsze stają się, z jednej strony, wytwarzane przez nie relacje (budowane w zmieniających się okolicznościach i kontekstach od-

\footnotetext{
${ }^{15}$ J. Sławiński, Krytyka literacka..., s. 147.

${ }^{16}$ Tamże, s. 150.

${ }^{17}$ Tamże.
} 
bioru tego samego tekstu literackiego). A z drugiej strony - jak pisał Adorno - „poznanie przedmiotu w jego konstelacji jest poznaniem procesu, który ten przedmiot w sobie zakumulował"18.

Po drugie, stawką w tworzeniu tak pomyślanej konstelacji jest nie tyle pokazanie, jak w toku recepcji zmienia się sposób rozumienia konkretnego dzieła literackiego; czy, jak i na ile to dzieło zostało rozpoznane i nie tyle - jak chce Sławiński - współtworzenie poprzez historię krytyki historii literatury, ile sama krytyka i ujawniany w ramach różnorodnych warunków i zależności wewnątrzkonstelacyjnych status języków krytycznych. Taki, konstelacyjny model historii krytyki literackiej nie redukuje krytyki literackiej ani do dyskursu sekundarnego wobec literatury (jak to ma miejsce w historii recepcji danego dzieła), ani do sposobu wyrażania/formułowania konkretnych filozoficznych, politycznych, społecznych, kulturowych idei (jak dzieje się to w przypadku badania krytyki literackiej w perspektywie określonych prądów czy programów literackich), ani do poziomu realizacji konkretnych (politycznych, programowych, osobistych) celów. Pozwala natomiast na uruchomienie relacji pomiędzy poszczególnymi tekstami i poszczególnymi perspektywami badawczymi, które te teksty uruchamiają, na postrzeganie ich wzajemnych, zmieniających się, układów i powiązań. Pozwala więc na jednoczesne uchwycenie krytyki literackiej w jej pojedynczych odsłonach, tj. w poszczególnych tekstach krytycznoliterackich - jako zapisanego świadectwa lektury kumulującej w danym historycznie czasie określone sposoby odczytania tekstu literackiego, oczekiwania odbiorcze, kryteria wartościowania, pozycjonowanie krytyki literackiej w polu literatury, wybory dokonywane przez konkretnego krytyka. Oraz - w konstelacyjnych układach - jako „migoczącą", zmienną całość, w której teksty krytycznoliterackie ujawniają, we wzajemnych relacjach, swoje znaczenia, uwikłania, ograniczenia czy roszczenia, „odbijają” znaczące przebiegi myślowe i uwarunkowania w polu literatury (np. Jakie podstawowe kategorie czytania literatury ujawniają się w takiej konstelacji i co je warunkuje? Kto pisze, z jakiego miejsca i jak to jest pozycjonowane w ówczesnym życiu literackim? Jaka jest skala i kontekst ocen konkretnego tekstu literackiego i na ile pokrywają się one z politycznymi czy światopoglądowymi podziałami? Jak perspektywa współczesności badacza zmienia wagę i znaczenia poszczególnych tekstów krytycznych?).

Konstelacje krytyczne dają więc możliwość pokazania krytyki w całej jej „materialności”, złożoności, nieciągłości i zmienności, bez ograniczających ją prób hierarchizowania i przyporządkowywania do "postępowania klasyfikującego”, eliminującego zdaniem Adorna, specyfikę badanego przedmiotu ${ }^{19}$. Zbudowany na takim rozumieniu konstelacji model badania krytyki literackiej jest zatem nie tyle ściśle pojętą metodą badawczą, lecz działa według mechanizmu podobnego „konstelacyjnej analizie”, która - jak pisał Ryszard Nycz - „oplata przedmiot otwartą, pełną luk i szczelin siecią różnorodnych (w tym sprzecznych) pojęć, które niejako «indagują» i aktywują stłumione czy zatarte jego sploty i warstwy, wyprowadzając na powierzchnię i czyniąc dostępną poznaniu jego unikatową złożoną teksturę"20.

\footnotetext{
${ }^{18}$ T.W. Adorno, Dialektyka negatywna, przekł. i wstęp K. Krzemieniowa, Warszawa 1986, s. 223-227, cyt. za: R. Nycz, Lekcja Adorna: tekst jako sposób poznania, albo o kulturze jako palimpseście, „Teksty Drugie” 2012, nr 3, s. 44.

${ }^{19}$ „Konstelacja rzuca światło na specyfikę przedmiotu, która dla postępowania klasyfikującego jest obojętna lub uciążliwa" - T.W. Adorno, Dialektyka negatywna, s. 44.

${ }^{20}$ R. Nycz, Lekcja Adorna, s. 44. Nycz wskazuje, że nie sposób przekształcić konstelacyjnej analizy w metodę, konstelacja jest bowiem zbyt zmienna, elastyczna i idiosynkratyczna.
} 


\title{
SŁOWA KLUCZOWE:
}

konstelacja

dyskurs krytyczny

\begin{abstract}
AbStrakT:
Celem artykułu jest wykorzystanie astronomicznej metafory konstelacji do badania krytyki literackiej. Wychodząc od kluczowych dla statusu pojęcia „konstelacji” ustaleń Waltera Benjamina, używającego tej metafory do refleksji o badaniu historii, poprzez Adorniańskie korekty sytuujące konstelację w polu badań estetycznych i proponowany przez Renée R. Trilling konstelacyjny model lektury, a także sposoby dotychczasowego wykorzystywania tej metafory w polskich badaniach nad krytyką, niniejszy szkic zmierza do ukazania konstelacji jako sposobu ujmowania krytyki literackiej bez totalizujących, ujednolicających klasyfikacji. Pokazuje, że „konstelacja krytyczna” pozwala na wydobycie jednostkowości dyskursów krytycznych, przy jednoczesnym odsłonięciu ich relacyjności i wielowymiarowego uwikłania $\mathrm{w}$ warunki pola literackiego (ze współczesnością ich badacza włącznie). Proponuje konstelacyjny model badania krytyki literackiej.
\end{abstract}




\section{historia sztuki \\ dialektyka}

\section{KONSTELACJA KRYTYCZNA}

\section{NOTA O AUTORZE:}

Katarzyna Trzeciak - badaczka i krytyczka literatury, doktor literaturoznawstwa, stypendystka Ministra Nauki i Szkolnictwa Wyższego. Zajmuje się estetyką i filozofią literatury, a także najnowszymi teoriami i metodologiami badań literackich. Publikowała m.in. w „Czasie Kultury”, „Wielogłosie”, „Pamiętniku Literackim”.

Dorota Kozicka - badaczka i krytyczka literatury, adiunkt w Katedrze Krytyki Współczesnej Wydziału Polonistyki na Uniwersytecie Jagiellońskim. Zajmuje się literaturą najnowszą oraz badaniami nad krytyką literacką. W ramach tych ostatnich zainteresowań opublikowała książki „Chamuly”, „gnidy” i „przemilczacze”. Antologia dwudziestowiecznego pamfletu polskiego (2011) oraz Krytyczne (nie)porządki: studia o współczesnej krytyce literackiej w Polsce (2012). Obecnie prowadzi grant Konstelacje krytyczne. Strategie krytyki literackiej XX i XXI wieku. 